\title{
Deteksi Kanker Berdasarkan Klasifikasi Microarray Data
}

\author{
Adiwijaya \\ Universitas Telkom Bandung, Indonesia \\ Email: adiwijaya @telkomuniversity.ac.id
}

\begin{abstract}
Abstrak
Kanker merupakan salah satu penyakit yang dapat menyebabkan kematian manusia didunia dan menjadi penyebab kematian terbesar setelah penyakit jantung. Karena itu diperlukan suatu teknologi DNA microarray yang digunakan untuk memeriksa bagaimana pola ekspresi gen berubah dalam kondisi yang berbeda, sehingga teknologi tersebut mampu men-deteksi seseorang terkena kanker atau tidak dengan analisis yang akurat. Besarnya dimensi pada microarray data dapat berpengaruh terhadap analisis ekspresi gen yang digunakan untuk mencari gen informatif, untuk itu diperlukan suatu metode reduksi dimensi dan klasifikasi yang baik sehingga mampu mendapatkan hasil maupun akurasi yang terbaik. Banyak teknik yang dapat diterapkan dalam DNA microarray, salah satunya BPNN Back Propagation Neural Network sebagai klasifikasi dan PCA sebagai reduksi dimensi, dimana keduanya telah teruji pada beberapa penelitian sebelumnya. Dengan menerapkan BPNN dan PCA pada beberapa jenis data kanker, didapatkan bahwa BPNN dan PCA mendapatkan hasil akurasi lebih dari $80 \%$ dengan waktu training time $0-4$ detik.
\end{abstract}

Kata kunci: kanker, klasifikasi, reduksi dimensi

\begin{abstract}
Cancer is one of the diseases that can cause human death in the world and become the biggest cause of death after heart disease. Therefore we need a DNA microarray technology which is used to examine how gene expression patterns change under different conditions, so that the technology is able to detect a person with cancer or not with accurate analysis. The size of the dimension in the microarray data can affect the gene expression analysis that is used to find informative genes, for that we need a good method of dimension reduction and classification so that it can get the best results and accuracy. Many techniques can be applied in DNA microarray, one of them is BPNN Back Propagation Neural Network as a classification and PCA as dimension reduction, where both have been tested in several previous studies. By applying BPNN and PCA on several types of cancer data, it was found that BPNN and PCA get more than $80 \%$ accuracy results with training time $0-4$ seconds.
\end{abstract}

Keywords: kanker, classification, dimension reductio

\section{PENDAHULUAN}

Kanker adalah salah satu penyakit yang menjadi penyebab utama kematian manusia diberbagai negara. Menurut WHO pada tahun 2012 terjadi 14 juta kasus baru dan 8,2 juta terkait kematian yang disebabkan oleh kanker, dan jumlah tersebut diperkirakan akan meningkan $70 \%$ selama dua dekade mendatang [1]. Karena itu, sangat diperlukan suatu teknologi yang mampu mendeteksi penyakit kanker lebih awal dengan analisis yang akurat, sehingga penyakit kanker dapat ditangani sejak dini.

Pada beberapa tahun terakhir, suatu analisis dan diagnosis kanker dilakukan dengan menggunakan microarray data. DNA microarray, merupakan suatu teknologi yang digunakan untuk memonitor suatu ekspresi data (gen) dalam jumlah yang sangat besar dan berbeda secara bersamaan. Teknologi microarray telah digunakan untuk diagnosis medis dan analisis gen, terutama untuk memeriksa bagaimana pola ekspresi gen berubah dalam kondisi yang berbeda. Dengan analisis data ekspresi gen berupa microarray tersebut, memungkinkan suatu medis untuk dapat mengetahui apakah seseorang terkena suatu kanker atau tidak. Maka dari itu microarray sangat memiliki peran dalam diagnosis kanker.

Adanya perbedaan antara jumlah gen yang diukur dan jumlah individu sampel yang ada beserta besarnya dimensi dari data tersebut sangat memiliki pengaruh terhadap analisis ekspresi gen dari suatu microarray yang akan digunakan untuk mengidentifikasi serta mencari gen informatif [2]. Klasifikasi ekspresi gen ataupun klasifikasi kanker adalah proses untuk mengidentifikasi gen informatif yang dapat digunakan untuk memprediksi kelas untuk pengujian sampel baru [3] dan merupakan salah satu kajian dalam bidang bioinformatika yang digunakan untuk analisis suatu kanker, untuk itu diperlukan suatu teknik atau skema yang efisien untuk klasifikasi yang tepat dari data ekspresi gen microarray tersebut yang memiliki kinerja tinggi beserta akurasi yang baik.

Pada penelitian data kanker yang digunakan untuk klasifikasi colon cancer, central nervous, leukimia yang berupa microarray. Teknik klasifikasi digunakan untuk menentukan suatu kelas pada data tersebut. Adapun skema klasfikasi yang diusulkan, yaitu dengan melakukan dengan tiga tahapan proses, diantaranya: preprocessing, reduksi dimensi, dan klasifikasi gen.

Para peneliti sudah melakukan penelitian terhadap teknik klasifikasi kanker berdasarkan microarray data. Berikut ini adalah beberapa literatur yang berkaitan dengan metode ini. Devi Arockia Vanitha [2], membangun skema Mutual Information-based Gene Selection (MI) dengan support vector machines (SVM) sebagai feature 
selection dan classifier pada microarray data, hasil akurasi yang diperoleh dari skema tersebut dengan menggunakan LOOCV mean accuracy rate didapatkan bahwa ANN (Artificial Neural Network) memiliki akurasi 0.5094, SVM dengan kernel Linear 0.6774, SVM dengan kernel RBF 0.6051, pada microarray data colon cancer. Sedangkan pada paper Seeja.K.R. [4], membangun skema F-Score dengan SVM sebagai feature selection dan classifier, skema tersebut mampu menghasilkan running time yang lebih cepat dibandingkan dengan ANN. Sedangkan pada paper Nurfalah.A [5], skema yang dibangunnya yaitu dengan menggunakan PCA dan MBP (Modified Backpropagation) sebagai reduksi dimensi dan klasifikasi microarray data, dari skema tersebut menghasilkan akurasi $96 \%$ untuk kanker ovarian, $76.92 \%$ untuk colon cancer, $97.14 \%$ untuk data leukimia.

Berdasarkan beberapa penelitian sebelumnya, maka pada penelitian ini skema yang diusulkan untuk deteksi kanker berdasarkan klasifikasi microarray data adalah kombinasi PCA dan SVM. Dimana pada tahap pengurangan dimensi akan dilakukan dengan menggunakan PCA, karena PCA telah banyak digunakan dan terbukti sangat efektif dalam pengurangan dimensi, dimana vektor data dari hasil proses PCA merupakan data yang representasinya telah optimal. Sedangkan pada tahap klasifikasi akan menggunakan support vector machines (SVM), dimana SVM dapat memecahkan klasifikasi yang kompleks. Dalam metode klasifikasi gen yang diuraikan oleh Furey et.al [6], SVM memiliki kinerja yang baik, dengan kernel sederhana untuk analisis microarray data.

\section{TEORITIS}

DNA microarray adalah teknologi yang digunakan untuk melihat urutan sekuens asam nukleat yang berada pada lokasi tertentu dan dapat digunakan untuk menganalisis beribu-ribu sampel pada waktu yang bersamaan. Prinsipnya adalah mengandalkan kemampuan DNA sampel yang telah dilabel dengan zat fluorescent untuk melakukan rekombinasi dengan probe yang telah ada pada chip microarray.

Aplikasi microarray banyak digunakan dalam deteksi kanker, dimana sel kanker mengalami abnormalitas dalam meng-ekspresikan gennya. Pada dasarnya, DNA microarray akan mengamati ekspresi genetik dari berbagai gen dengan jumlah yang mencapai ratusan bahkan ribuan secara bersamaan. Dalam analisis kanker, digunakan DNA normal dan DNA kanker yang kemudian akan di hibridisasi lalu akan dibaca dengan menggunakan laser (scanner). Klasifikasi data microarray merupakan salah satu kajian dalam bidang bioinformatika yang digunakan, salah satunya yaitu untuk analisis suatu kanker. Klasifikasi pada deteksi kanker, dapat dilakukan dengan mengelompokkan data ke dalam kelas yang sudah ditetapkan.

Adapun beberapa peneliti yang telah bekerja untuk melakukan klasifikasi microarray data yaitu, Moorthy [14] mengusulkan skema klasifikasi menggunakan algoritma. Random Forest pada microarray data. Data yang digunakan adalah data Adenocarcinoma, Brain, Breast2, Breast3, Colon, Leukemia, Lymphoma, NCI60, Prostate, $S R B C T$. Untuk klasifikasi meggunakan Random Forest mereka melakukan uji coba pada nilai OOB error rate dengan kondisi, yaitu (1) nilai OOB error rate terendah dan jumlah subset paling sedikit (2) nilai OOB error rate terendah dan jumlah subset paling banyak (3) proses standar atau default algoritma Random Forest. Dari penelitiannya diperoleh akurasi klasifikasi standar atau default algoritma Random Forest untuk seleksi gen selalu lebih rendah dari OOB error rate terendah dan jumlah subset paling sedikit dan OOB error rate terendah dan jumlah subset paling banyak.

Vanitha [15] melakukan klasifikasi menggunakan algoritma Support Vector Mechine (SVM) dengan menggunakan 2 microarray data yaitu Colon cancer dan Lymphoma. Mutual information (MI) antara gen dan label kelas digunakan untuk mengidentifikasi gen yang informatif. Gen yang terpilih digunakan untuk learning menggunakan SVM dan evaluasi pada penelian ini menggunakan metode Leave-one-Out Cross Validation (LOOCV). Metode yang diusulkan pada penelitian ini mampu mengurangi dimensi fitur dengan mengidentifikasi subset gen yang paling informatif serta memperbaiki akurasi klasifikasi. Tsun-Chen Lin, Ru-Sheng Liu, Ya-Ting Chao, and Shu-Yuan Chen [20] tujuan dari penelitian yang dilakukan adalah untuk mengeksplorasi penggunaan data ekspresi gen dalam membedakan jenis kanker heterogen. Mereka menggunakan hybrid learning methodology algoritma genetika (GA) dan jaringan syaraf tiruan (JST) untuk menemukan subkumpulan gen yang optimal untuk klasi_kasi jaringan / kanker. Metode yang diusulkan diuji pada dua dataset microarray yaitu NCI60 dan GCM. Hasil dari penelitian yang dilakukan menunjukkan metode GA dan ANN tidak hanya unggul dalam pendekatan prediksi tetapi juga dapat mengurangi jumlah gen prediktif yang diperlukan dalam klasifikasi.

Campos [18] pada penelitian nya menerapkan algoritma bayesian network untuk proses klasifikasi menggunakan microarray data, dimana dataset yang digunakan adalah Breast-cancer, CNS, Colon-cancer, DLBCL-MIT, DLBCL-Stanford, Leukemia ALL-AML, Leukemia- MLL, Lung-cancer, Prostate-tumor. Pada penelitiannya, ekspresi gen dengan 3 cara, yaitu (1) klasifikasi Bayesian yang diinduksi dari data microarray. (2) skema preprocessing untuk data ekspresi gen digunakan menginduksi pengklasifikasi Bayesian, dan (3) evaluasi Bayesian yang berbeda untuk jenis data.

Lavanya [18] membangun kerangka komprehensif yang menggabungkan fitur seleksi dan teknik klasifikasi. Teknik klasifikasi yang digunakan adalah algoritma Naive Bayes. Sedangkan untuk fitur seleki menggunakan pengukuran T-Test, Chi-Square Test yang digunakan untuk memilih kemungkinan gen yang berhubungan dengan kanker dari data ekspresi gen microarray yang besar. Dari kerangka klasifikasi yang dibangun berhasil melakukan klasifikasi sampel baru seperti yang terinfeksi atau normal. Deegalla [19] melakukan penelitian klasifikasi pada microarray data menggunakan algoritma KNN. Dataset yang digunakan diantara nya 
Colon Tumor, Leukemia, Central Nervous, SRBCT, Lymphoma, Brain, NCI60, dan Prostate. Sebelum melakukan klasi_kasi mereka melakukan reduksi fitur yang mana ada beberapa metode reduksi fitur yang digunakan, yaitu Principal Component Analysis (PCA), Random Projection (RP), Partial Least Squares (PLS) and Information Gain(IG). Hasil penelitian tersebut menunjukan bahwa PCA dan PLS mencapai akurasi terbaik dengan komponen yang lebih sedikit daripada dua metode lainnya. Kesimpulan utama dari penelitian ini adalah bahwa pilihan metode reduksi fitur dapat menjadi sangat penting saat klasifikasikan microarray menggunakan algoritma KNN. Li [16] pada penelitian ini dilakukan klasifikasi menggunakan beberapa metode seperti LibSVMs, C4.5, BaggingC4.5, AdaBoostingC4.5, dan Random Forest pada tujuh kumpulan data kanker Microarray (Breast Cancer, Lung Cancer, Lymphoma, Leukemia, Colon, Ovarian, and Prostate). Hasil dari penelitian menunjukkan bahwa semua metode ensemble mengungguli C4.5. Hasil percobaan juga menunjukkan bahwa kelima metode tersebut mendapatkan keuntungan dari preprocessing data, termasuk pemilihan gen dan diskritisasi, dalam akurasi klasifikasi.

Vanitha [13] mengusulkan skema klasifikasi microarray data dengan menggunakan Mutual Information untuk mencari gen informatif dan Support Vector Machines (SVM) sebagai classifier pada ekspresi gen, hasil dari $S V M$ dan $M I$ ternyata dapat menangani sejumlah besar fitur (gen) dan sejumlah kecil pola (sampel) yang menjadi kendala pada skema klasifikasi ekspresi gen microarray. Bai [12], membangun sebuah framework menggunakan PCA dan Backpropagation untuk mengklasifikasikan data microarray. Datam paper tersebut, dataset mikroarray yang digunakan yaitu data kanker ovarian dengan akurasi 96\%, data kanker colon dengan akurasi 95\%, dan data kanker leukimia dengan akurasi $97 \%$. Dalam penelitian tersebut ditemui kendala berupa waktu training yang lama, yaitu sekitar 20 sampai 23 detik untuk setiap data. Hieuin [13], mengembangkan framework sebelumnya dengan mengimplementasikan PCA dengan Singular Value Decomposition (SVD). Experiment tersebut membandingkan metode yang diajukan dengan Extreme Learning Method (ELM) dan memiliki akurasi sebesar 83.6\%. Sedangkan Adiyasa [5], mengusulkan kerangka kerja alternatif untuk mengatasi kekurangan dari algoritma Backpropogation dengan menggunakan kombinasi Principal Component Analysis (PCA) dan Modified Backpropagation (MBP), dalam skema yang diusulkan telah dihasilkan suatu algoritma MBP mampu melakukan training lebih cepat dimana kecepatan training menjadi kendala pada algoritma Backpropagation standar. Seperti apa yang sudah dilakukan Nhita[9] dapat mengubah dari Back Propagation biasa diubah menjadi Evolving Neural Network yaitu gabungan dari GA dan Back Propagation. Banyaknya metode yang digunakan untuk klasifikasi microarray data dapat menjadi bahan pertimbangan untuk mengembangkan metode yang sudah ada.

\section{ANALISA DAN PEMBAHASAN}

Data yang digunakan diperoleh dari Kent-Ridge Biomedis data Repository [10], dimana pada tabel data terdapat beberapa tipe kanker. Pada tabel jumlah kelas yang akan di klasifikasikan. Pada tabel samples, merupakan jumlah data sampel yang tersedia. Pada tabel feature, merupakan jumlah atribut (penilaiaan) pada tiap sampel.

Tabel 1. Spesifikasi Data

\begin{tabular}{llll}
\hline Data & $\begin{array}{l}\text { Jumlah } \\
\text { Kelas }\end{array}$ & Sample & Feature \\
\hline Colon & 2 & $62(22$ Positif, 40 Negatif) & 2001 \\
Leukimia & 3 & $72(24$ ALL, 28 AML, 20 MLL) & 12582 \\
Ovarian & 2 & $253(91$ Normal, 162 Cancer $)$ & 15155 \\
Central & 2 & $60(21$ Class1, 39 Class0) & 7129 \\
Nervous & & & \\
Lung Cancer & 2 & 181 (31 Mesothelioma, 150 ADCA) & 12533 \\
Prostate Tumor & 2 & $156(77$ Tumor, 79 Normal) & 12600 \\
\hline
\end{tabular}

Adapun skema umum dalam klasifikasi gene expression data (microarray), dimana akan dilakukan training dan testing terhadap microarray data dengan tahapan preprocessing, reduksi dimensi, dan klasifikasi. Adapun skema umumnya dapat dilihat pada Gambar 1 berikut ini.

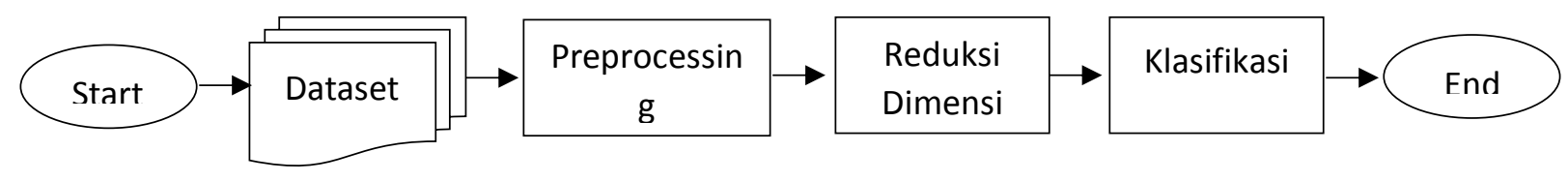

Gambar 1. Skema Umum Proses Klasifikasi data Microarray

Berdasarkan gambar diatas dapat dijelaskan bahwa:

- Dataset, dalam proses ini dilakukan pengumpulan data dari sumber [10] yang sudah tersedia dalam 
beberapa kelompok kanker yaitu Breast, Colon, Ovarian, Prostate, Central Nervous, Lung, Leukimia. Setiap dataset terbagi menjadi dua yaitu dataset training dan dataset testing

- Preprocessing, dalam proses ini hanya beberapa dataset saja yang menjalaninya yaitu cleansing data dari fitur yang kosong atau sama untuk seluruh kelasnya [11]. Tidak hanya itu, namun pada preprocessing ini juga untuk memisah data training dan testing menggunakan Cross Validation untuk beberapa dataset yang belum dipisahkan.

- Reduksi dimensi diperlukan karena Microarray data memiliki dimensi serta kompleksitas sangat tinggi, untuk itu diperlukan suatu proses yang dapat mengurangi kompleksitas dari microarray data tersebut. Pengurangan kompleksitas tersebut bertujuan untuk meminimalisir kesalahan. Reduksi dimensi bertujuan untuk mengambil fitur terpenting dengan threshold tertentu yang akan menghasilkan input untuk dilakukan klasifikasi. Reduksi dimensi bisa dilakukan dengan melalui feature slection atau feature extraction. Beberapa metode reduksi dimensi akan digunakan seperti Minimum Redundancy Maximum Relevance (mRMR), Mutual Information, PCA, Relief Method, dan lain sebagainya.

- Klasifikasi dilakukan setelah data sudah siap proses. Klasifikasi ini dibagi menjadi tiga proses. Pada proses yang pertama yaitu training akan dilakukan proses learning terhadap datasetnya yang menghasilkan suatu model. Proses selanjutnya yaitu testing akan dilakukan proses pengklasifikasian yang menghasilkan class dan dibandingkan dengan class target. Terakhir class hasil klasifikasi dan class target akan diproses untuk menghitung akurasi. Klasifikasi dilakukan dengan beberapa metode seperti Neural Network, Bayesian, Decission Tree dan lain-lain.

Pada bagian ini, dibahas mengenai hasil implementasi klasifikasi dari tujuh data kanker yang diperoleh dari Kent-Ridge Biomedical Data Repository [10]. Implementasi dilakukan dengan menerapkan beberapa kombinasi metode antara reduksi dimensi dan klasifikasi. Adapun hasil yang diperoleh, sebagai berikut.

Tabel 2. Perbandingan Akurasi Hasil Implementasi

\begin{tabular}{clccc}
\hline No & Ref & Metode Reduksi Dimensi & Metode Klasifikasi & $\begin{array}{c}\text { Avg Max } \\
\text { Akurasi }\end{array}$ \\
\hline 1 & {$[5]$} & Principal Component Analysis (PCA) & Back Propagation (BP) & $91.77 \%$ \\
2 & {$[21]$} & Principal Component Analysis (PCA) & Support Vector Machine (SVM) & $94.98 \%$ \\
3 & 21 & Principal Component Analysis (PCA) & Modified Back Propagation (MBP) & $96.07 \%$ \\
4 & {$[7]$} & Mutual Information & Bayesian Network & $88 \%$ \\
5 & {$[7]$} & Mutual Information & Naïve Bayes & $91 \%$ \\
6 & {$[8]$} & Relief Method & Support Vector Mechine (SVM) & $66.67 \%$ \\
7 & {$[8]$} & Relief Method & Artificial Neural Network (ANN) & $66.67 \%$ \\
8 & {$[8]$} & Relief Method & Random Forest & $75 \%$ \\
9 & {$[22]$} & Relief Method & Random Forest with clustering & $95.8 \%$ \\
\hline
\end{tabular}

Hasil tersebut memiliki perbedaan penggunaan jumlah dan jenis dataset. Secara keseluruhan terdapat tujuh dataset yang digunakan oleh penelitian diatas. Dari tujuh dataset, minimal yang digunakan dalam satu kombinasi metode adalah tiga dataset. Untuk itu, dilakukan rata-rata akurasi dari maksimum nilai dalam satu dataset dan satu metode yang digunakan. Pendeketaan klasifikasi yang dilakukan ada lima yaitu Neural Network, Decission Tree, Teorema Bayes, Nearest Neighbour, dan SVM. Dari lima pendekatan tersebut dilakukan beberapa metode atau algoritma yang telah disebutkan pada Tabel 2. Tidak hanya metode klasifikasi, reduksi dimensi dilakukan dengan tiga metode yaitu PCA, Relief Method, dan Mutual Information. Metode klasifikasi dan metode reduksi dimensi dikombinasikan untuk melihat perilaku metode-metode tersebut terhadap data Microarray.

Berdasarkan Tabel 1, didapatkan beberapa kombinasi metode reduksi dimensi dan metode klasifikasi dari hasil penelitian-penelitian yang sudah dilakukan. Tidak semua metode klasifikasi mendapatkan hasil yang baik setelah dikombinasikan reduksi dimensi tertentu seperti Naïve Bayes dan Relief Method. Namun Naïve Bayes dapat menghasilkan akurasi tinggi setelah dikombinasikan dengan Mutual Information. Hal tersebut membuktikan bahwa setiap metode mempunyai karakteristik masing-masing yang dapat berbenturan jika tidak sinkron. Hasil tersebut dilakukan dengan data-data yang sudah disediakan oleh Kent-Ridge Biomedical [10]. Hasil kombinasi Relief Method dan Random Forest (with clustering) dengan rata-rata akurasi maksimal sebesar 95.8\%. Sementara itu, hasil kombinasi PCA dan Modified Backpropagation sedikit lebih unggul dalam performansi, yakni 96,7\%.

Berikut disajikan hasil klasifikasi menggunakan PCA dan Evolving Neural Network (ENN) disajikan pada Gambar 3. Adapun hasil yang telah diperoleh untuk 2 data set kanker (leukemia dan colon tumor) rata-rata akurasinya disajikan dalam Gambar 2. 


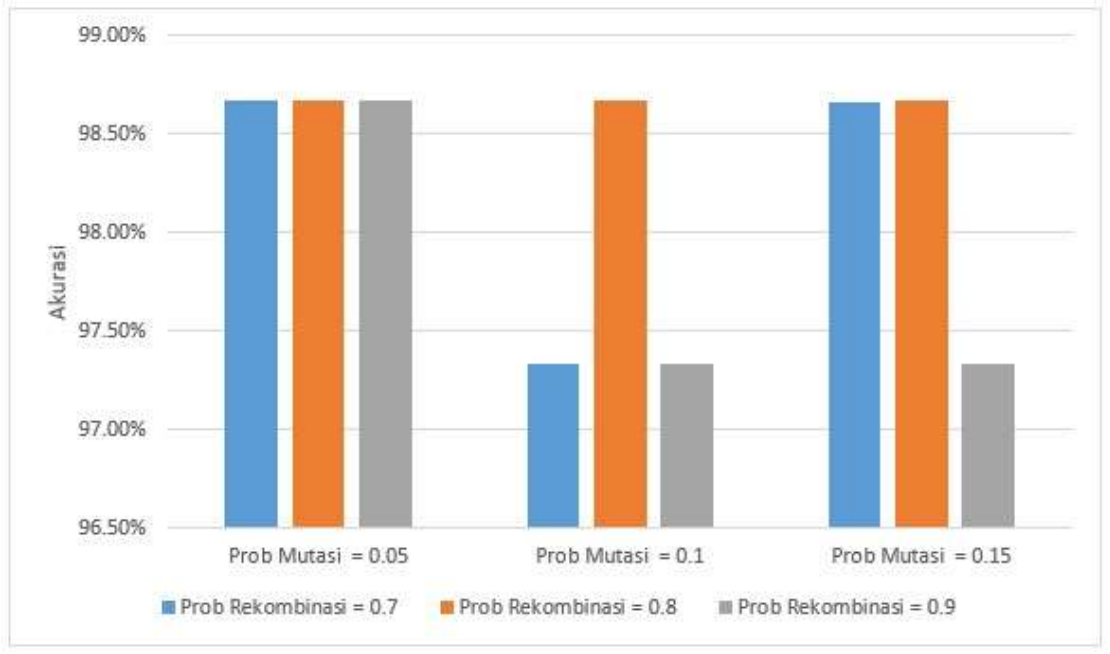

Gambar 2. Hasil Klasifikasi menggunakan PCA - ENN

Probabilitas rekombinasi 0,7 memberikan hasil akurasi yang lebih stabil. Secara umum, hasil akurasi akan stabil jika probabilitas mutasinya kecil karena sebenarnya GA meniru konsep di alam yg menyatakan proses mutasi memiliki kecenderungan untuk menghasilkan individu yg lebih buruk. Tetapi mutasi diperlukan jika individu yg dihasilkan dari proses rekombinasi tingkat variasinya kecil.

\section{KESIMPULAN}

Berdasarkan hasil penelitian yang telah didapatkan, maka kesimpulan yang dapat diambil dari penelitian ini adalah sebagai berikut. Beberapa metode klasifikasi teruji dapat melakukan klasifikasi ekspresi gen untuk mendeteksi kanker dari Kent Ridge Bio-medical Dataset dengan nilai performansi maksimal 98.71\%. Proses reduksi dimensi dapat dilakukan setelah melakukan preprocessing cleansing dataset dan cross validasi. Tiga metode terbukti dapat digunakan untuk melakukan reduksi dimensi. Atribut yang terbaik digunakan berbeda-beda pada setiap data. Metode klasifikasi dan metode reduksi dimensi mempunyai karakteristik masing-masing jika dikombinasikan. Hal ini ditunjukkan saat sistem dibangun dengan suatu metode klasifikasi yang sama dapat dihasilkan akurasi berbeda ketika reduksi dimensi berbeda.

\section{REFERENCES}

[1] World Health Organization, Cancer fact sheet, http://www.who.int/mediacentre/factsheets/fs297/en/index.html, ccessed at March 2nd 2016.

[2] Vanitha, C.D.A., Devaraj, D. and Venkatesulu, M., 2015. Gene Expression Data Classification Using Support vector machines and Mutual Information-based Gene Selection. Procedia Computer Science, 47, pp.13-21.

[3] Siang, T.C., Soon, T.W., Kasim, S., Mohamad, M.S., Howe, C.W., Deris, S., Zakaria, Z., Shah, Z.A. and Ibrahim, Z., 2015. A Review of Cancer Classification Software for Gene Expression Data. International Journal of Bio-Science and Bio-Technology, 7(4), pp.89108 .

[4] KR, S., 2011. Microarray Data Classification Using Support Vector Machine. International Journal of Biometrics and Bioinformatics (IJBB), 5(1), p.10.

[5] Nurfalah A.,Adiwijaya, Suryani A.A ,"Cancer Detection Based On Microarray data Classification Using PCA And Modified Backpropogation", Far East Journal of Electronics and Communications.2015

[6] Furey, T.S., Cristianini, N., Duffy, N., Bednarski, D.W., Schummer, M. and Haussler, D., 2000. Support vector machines Classification And Validation Of Cancer Tissue Samples Using Microarray Expression Data. Bioinformatics, 16(10), pp.906-914.

[7] Purbolaksono, M.D., Widiastuti, K.C., Mubarok, M.S. and Ma'ruf, F.A., 2018, March. Implementation of mutual information and bayes theorem for classification microarray data. In Journal of Physics: Conference Series (Vol. 971, No. 1, p. 012011). IOP Publishing.

[8] Aydadenta, H., 2018, March. On the classification techniques in data mining for microarray data classification. In Journal of Physics: Conference Series (Vol. 971, No. 1, p. 012004). IOP Publishing.

[9] Nhita, F. and Adiwijaya, U.N., 2014. Forecasting Indonesian Weather through Evolving Neural Network (ENN) based on Genetic Algorithm. In The Second International Conference on Technological Advances in Electrical, Electronics and Computer Engineering (TAEECE2014) (pp. 78-82). The Society of Digital Information and Wireless Communication.

[10] Jinyan Li, Kent-ridge bio-medical data set repository, School of Computer Engineering Nanyang Technological University, Singapore, Downloaded at January 2013 from URL:http://levis.tongji.edu.cn/gzli/data/mirror-kentridge.html

[11] Adiwijaya, Wisesty, U.N. and Nhita, F., 2014. Studi of line search techniques on the modified backpropagation for forecasting of weather data in Indonesia. Far East Journal of Mathematical Sciences, 86(2), p.139.

[12] Bai Anita and S. K. Rath. Classification and Clustering using Intelligence Techniques: Application to microarray cancer data. Master Thesis of Department of Computer Science and Engineering National Institute of Technology Rourkela, India, 2013.

[13] Hieu Trung Huynh, Jung-Ja Kim, Yonggwan Won., 2009. Classification Study on DNA Microarray with Feed Forward Neural Network Trained by Singular Value Decomposition. International Journal of Bio-Science and Bio Technology, 1(1).

[14] Moorthy, K. and Mohamad, M.S., 2012. Random forest for gene selection and microarray data classification. In Knowledge Technology (pp. 174-183). Springer, Berlin, Heidelberg 
[15] Vanitha, C.D.A., Devaraj, D. and Venkatesulu, M., 2015. Gene expression data classification using support vector machine and mutual information-based gene selection. procedia computer science, 47 , pp.13-21.

[16] Li, T., Zhang, C. and Ogihara, M., 2004. A comparative study of feature selection and multiclass classification methods for tissue classification based on gene expression. Bioinformatics, 20(15), pp.2429-2437.

[17] De Campos, L.M., Cano, A., Castellano, J.G. and Moral, S., 2011, November. Bayesian networks classifiers for gene-expression data. In Intelligent Systems Design and Applications (ISDA), 2011 11th International Conference on(pp. 1200-1206). IEEE.

[18] Lavanya, C., Nandihini, M., Niranjana, R. and Gunavathi, C., 2014. Classification of microarray data based on feature selection method. International Journal of Innovative Research in Science, Engineering and Technology, 3(1).

[19] Deegalla, S. and Boström, H., 2007, December. Classification of microarrays with knn: Comparison of dimensionality reduction methods. In International Conference on Intelligent Data Engineering and Automated Learning (pp. 800-809). Springer, Berlin, Heidelberg

[20] Lin, T.C., Liu, R.S., Chao, Y.T. and Chen, S.Y., 2006, August. Multiclass microarray data classification using GA/ANN method. In Pacific Rim International Conference on Artificial Intelligence (pp. 1037-1041). Springer, Berlin, Heidelberg.

[21] Husna Aydadenta, Adiwijaya, (2018), A Clustering Approach for Feature Selection in Microarray Data Classification using Random Forest, Journal of Information Processing System 14(5).

[22] Adiwijaya, U. N. Wisesty, E. Lisnawati, A. Aditsania, D. S. Kusumo, (2018). Dimensionality Reduction using Principal Component Analysis for Cancer Detection based on Microarray Data Classification, Journal of Computer Science 14(10). 